\title{
Multiple and giant perforating pilomatrixoma: a case report
}

\section{Sarra Harbaoui, Soumaya Youssef, Imene Ben Lagha, Najla Daadaa, Kahena Jaber, Mohamed Raouf Dhaoui, Nejib Doss}

\author{
Department of Dermatology, Military Hospital of Tunis, Tunisia
}

Corresponding author: Dr. Sarra Harbaoui, E-mail: sarraharbaoui0101@gmail.com

\begin{abstract}
Pilomatrixoma is benign skin tumor that originates from the pilosebaceous follicle. In most cases it presents as a solitary asymptomatic and a firm subcutaneous nodule on the head, neck or upper extremities. Herein, we report a case of 27-year-old patient who presented with a history of multiple tumors of the upper back, the left arm, the forearms, the proximal third of the right thigh and the scalp. The biopsy showed a benign tumoral proliferation on the dermis and hypodermis with a transepidermal elimination of shadow cells islands on the perforated lesion. Pilomatrixoma is an adnexal skin tumor which may be difficult to diagnose due to different clinical and cytological findings. This diagnosis must be evoked in every patient presenting with a firm subcutaneous tumor of the head, neck or upper extremities. The histological examination confirms the diagnosis and the treatment is surgical excision.
\end{abstract}

Key words: Pilomatrixoma; Multiple; Perforating

\section{INTRODUCTION}

Pilomatrixoma, also termed pilomatricoma, trichomatricoma or calcifying epithelioma of Malherbe, is a benign skin tumor that originates from the matrix of the hair root. It's a relatively rare condition [1] which is frequently misdiagnosed clinically and the correct diagnosis is only histological $[1,2]$. This tumor presents as a solitary asymptomatic, firm, and skin-colored faint blue/red nodule in the deep dermis and subcutaneous tissue, with an average size of 0.5 to $3.0 \mathrm{~cm} \mathrm{[3].}$ However, giant pilomatrixomas (more than $5 \mathrm{~cm}$ ) have been reported in a few cases [4]. Pilomatrixoma is most commonly seen on the head and neck region followed by the upper extremities [5]. Although it can be seen in all ages and sexes; it is most often encountered in first two decades of life and females [1,4-9].

\section{CASE REPORT}

A 27-year-old white man, presented with a history of multiple tumors of the upper back, the left arm, the forearms, the proximal third of the right thigh and the scalp. He reported first noticing of these masses on the left arm, approximately one year earlier, since then, this lesion had rapidly increased in size and other lesions had progressively appeared.

He denied any history of trauma, and reported some discomfort in the left arm secondary to the size of the lesion in this area. His past medical history was unremarkable. Physical examination revealed a domeshaped, polypoïd, stony and movable tumor measuring $10 \times 8 \times 3 \mathrm{~cm}$, on the distal third of the left arm with a blue-red overlying skin showing telangiectatic vessels and stretch marks (Fig. 1). Besides, examination showed four painless and freely-movable, firm subcutaneous nodules ranging from 0,5 to $2 \mathrm{~cm}$ in diameter on the right upper back, the posterior forearms and the occipital region of the scalp. The overlying skin was normal. We also found a well-demarcated large area of thick, keloid, blue-red skin, measuring $7 \mathrm{~cm}$ in largest diameter and presenting a firm ulcerated, crumbly and spontaneously bleeding tumor on the

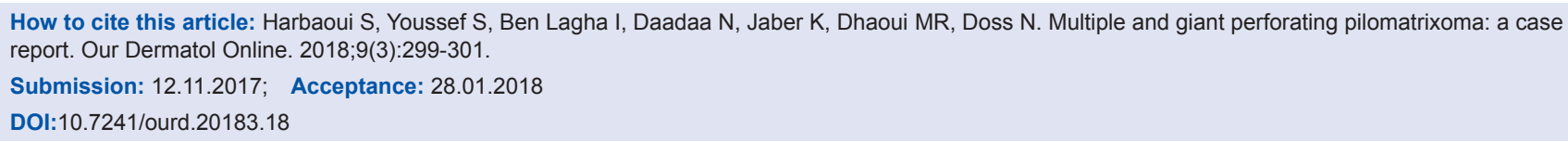




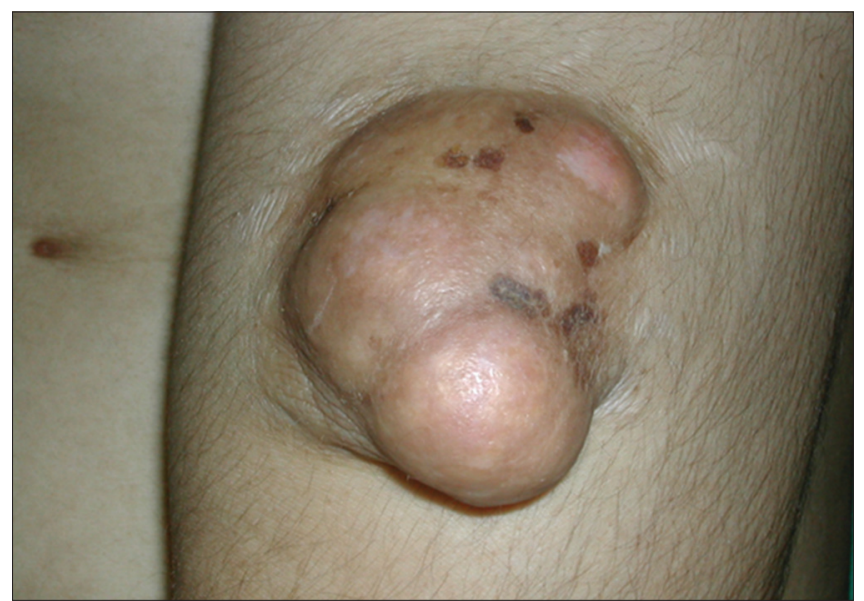

Fig ure 1: Dome-shaped, polypoïd, stony and movable tumor measuring $10 \times 8 \times 3 \mathrm{~cm}$, on the distal third of the left arm.

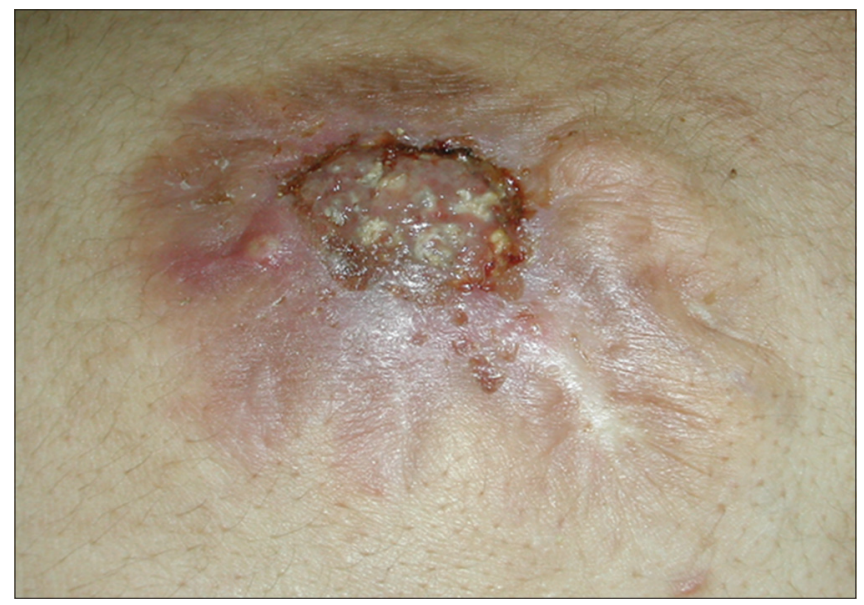

Figure 2: Ulcerated, crumbly and spontaneously bleeding tumor on the upper back.

upper back (Fig. 2). Histopathologic examination found a benign tumoral proliferation in the dermis and hypodermis which was composed of scattered foci and islands of basophilic and shadow cells in an inflammatory stroma with a granulomatous reaction with foreign body giant cells (Fig. 3). The perforated lesion shows a trans epidermal elimination of shadow cells islands (Fig. 4). Prior to the study, patient gave written consent to the examination and biopsy after having been informed about the procedure.

\section{DISCUSSION}

Pilomatrixoma is a relatively rare benign skin tumor. In fact, it has been reported to be the most common cutaneous adnexal tumor in patients younger than 20 years [8]. Up to $40 \%$ of pilomatrixomas arise before the age of 10 years and more than $60 \%$ of cases in the first two decades $[6,8,9]$. Most studies report a slight

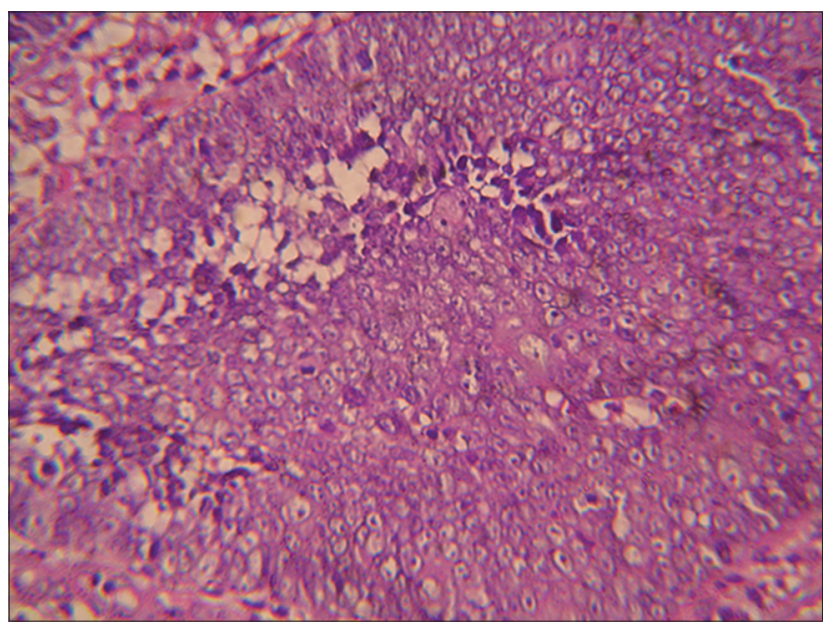

Figure 3: Scattered foci and islands of basophilic and shadow cells in the dermis and hypodermis.

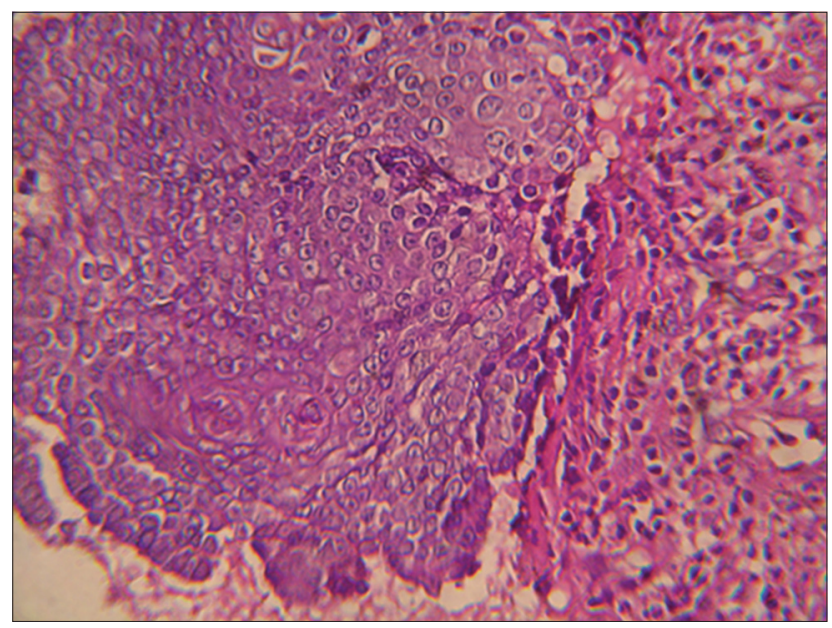

Figure 4: Trans epidermal elimination of shadow cells islands.

preponderance in females $[1,4,7]$ and it seems that this tumor occurs usually in Caucasians when compared with Asians and African-Americans [4,8].

The head and the neck followed by upper extremities are the most frequent localizations of pilomatrixoma with up to $40 \%$ of cases occurring on the head $[6,8,10]$ perhaps due to the higher hair follicle density in the scalp.

Clinically, pilomatrixomas present as solitary, firm to hard, painless, dermal or subcutaneous nodules ranging from 0,5 to $3 \mathrm{~cm}$; although pilomatrixomas over $10 \mathrm{~cm}$ in diameter have rarely been reported in literature $[1,4,10]$. Multiple or recurring pilomatrixomas are rarely seen and can be associated with myotonic dystrophy, Gardner syndrome, Turner syndrome, trisomy 9, spina bifida or sarcoidosis [6]. The overlying skin may be normal or have a reddish or bluish hue in $24 \%$ of cases $[1,3,8]$. 
The diagnosis may be reached by physical examination, imaging and cytology; however, there is a large number of misdiagnosis $[1,3,6]$. The differential diagnosis includes dermoid cysts, branchial cleft remnants, pre-auricular sinuses, sebaceous cysts, hemangiomas or malignant soft tissue tumors $[1,3]$. Pilomatrixoma do not regress or disappear spontaneously and transdermal elimination has rarely been reported as perforating or ulcerating pilomatricoma and this was noted in our patient [4].

The present case report is consistent with the published literature in terms of incorrect provisional diagnosis, and it's original in terms of the age of first appearance of the disease, the number of lesions, their various appearance, some atypical localizations [2,3] and the perforating histological feature.

\section{CONCLUSION}

Pilomatricoma is an adnexal skin tumor which may occur at any age especially in the two first decades. This diagnosis must be evoked in every patient presenting with a firm subcutaneous tumor of the head, neck or upper extremities. The histological data confirm the diagnosis and the treatment is surgical.

\section{CONSENT}

The examination of the patient was conducted according to the Declaration of Helsinki principles.

\section{REFERENCES}

1. Aydın S, Bilmez ZE, Erdogdu S, Altintoprak N, Kayipmaz Ş. Complicated Giant Pilomatrixoma of the Parotid Region. J Maxillofac Oral Surg. 2016;15:111-5.

2. Piel S, Denisjuk N, Schadendorf D, Dissemond J. Giant Pilomatricoma: A Benign Tumor in an Uncommon Presentation. J Pediatr. 2009;154:623.

3. Souto MPA, Matsushita M de M, Matsushita G de M, Souto LRM. An unusual presentation of giant pilomatrixoma in an adult patient. J Dermatol Case Rep. 2013;7:56-9.

4. Nadershah M, Alshadwi A, Salama A. Recurrent giant pilomatrixoma of the face: a case report and review of the literature. Case Rep Dent. 2012;2012:197-273.

5. Gupta R, Verma S, Bansal P, Mohta A. Pilomatrixoma of the Arm: A Rare Case with Cytologic Diagnosis. Case Rep Dermatol Med. 2012;2012:257405.

6. Schwarz Y, Pitaro J, Waissbluth S, Sam J. Daniel. Review of pediatric head and neck pilomatrixoma. Int J Pediatr Otorhinolaryngol. 2016;85:148-53.

7. Simi CM, Rajalakshmi T, Correa M. Pilomatricoma: A tumor with hidden depths. Indian J Dermatol Venereol Leprol. 2010;76:543-6.

8. Levy J, Ilsar M, Deckel Y, Maly A, Anteby I, Pe'er J. Eyelid pilomatrixoma: A description of 16 cases and a review of the literature. Surv Ophthalmol. 2008;53:526-35.

9. Topal IO, Singer R, Kocaturk Goncu OE, Topal Y, Yarkkkaya E, Sahin IM. An ulcerated giant pilomatricoma mimicking malignancy. J Dtsch Dermatol Ges. 2015;13:329-30.

10. Kumaran N, Azmy A, Carachi R, Raine PA, Macfarlane JH, Howatson AG. Pilomatrixoma accuracy of clinical diagnosis. J Pediatr Surg. 2006;41:1755-8.
Copyright by Sarra Harbaoui, et al. This is an open-access article distributed under the terms of the Creative Commons Attribution License, which permits unrestricted use, distribution, and reproduction in any medium, provided the original author and source are credited.

Source of Support: Nil, Conflict of Interest: None declared. 